Archaeological Journal

\title{
Further Remarks on Jade
}

\section{James Hilton F.S.A.}

To cite this article: James Hilton F.S.A. (1891) Further Remarks on Jade, Archaeological Journal, 48:1, 162-173, DOI: $10.1080 / 00665983.1891 .10852473$

To link to this article: http://dx.doi.org/10.1080/00665983.1891.10852473

$$
\text { 曲 Published online: } 15 \text { Jul } 2014 .
$$

Submit your article to this journal $\pi$

Q View related articles ¿ 


\section{FURTHER REMARKS ON JADE.}

By JAMES HILTON, F.S.A.

It will be in the recollection of readers of the Archceological Journal that volume xlv. contains a paper of "Remarks" as to the archæological relations of the stone or mineral substance known as Jade; a few words of recapitulation will connect it with what is now to follow. We are familiar with many forms of stone implements, tools, hammers, scrapers, weapons, spear and arrow heads, \&c., found in all parts of the world where ancient tribes of mankind have had their habitations; they are to be seen in every variety of condition, from the roughest chipped forms up to a high perfection of shape and polish. Any hard stone, particularly flint, was made use of for the purpose. Jade was used as opportunity occurred for so doing, being especially fit in consequence of its tough and hard qualities; examples, however, are comparatively rare. The localities where jade is commonly known to exist in situ are extremely few, such as the mountains in northern China, Burmah, New Zealand, some of the Pacific Islands, and, as recently reported, one or two localities in Europe, but none in Britain. Boulders or pieces of jade of unknown origin have been found on the European continent, also in some northern regions of America.

It is in vain to speak of stone or jade implements with reference to any chronological date; it may be supposed that as metal came into use stone weapons became obsolete, except among savage tribes, who had no access to metal. Thus is our enquiry bounded on one side by remote antiquity, and on the other by the periods of discovery of new countries by navigators, as recorded in comparatively 
modern history ; and as it is impossible to assign to stone implements any definite age, and we are compelled to regard them all as belonging to a pre-historic period, or at least to a vague period outside the pale of history, or even of tradition, they may be thousands of years old, while some in particular instances, with equal probability, may not be older than 200 years. Perhaps non-historic is the appropriate term.

We are concerned in tracing out the origin of the jade implements which have been found here and there in Europe, and particularly in Switzerland and in the district of Carnac in Brittany; any such discovery suggests the question, whence came the material and by what means it was removed from any one of the remote localities already mentioned, which, it has been assumed, were the only possible countries whence it could have been procured. It has been held as a true inference, that as no jade rock is known in situ in Europe, the introduction of any jade object into Europe must be owing either to man's agency, or to the occurrence of stray bits of the stone or boulders of that material, naturally transported by causes which geologists can appreciate; both of these agencies carry our investigations back to a period of remote antiquity. My "Remarks" above alluded to will help to a more extended pursuit of the subject with the aid of any new information that may be available. The literature of jade is scattered about in English, German, French, and American books and periodicals, and much is consequently difficult of access. Very few investigators have the opportunity of knowing of all that is recorded on the subject.

The motive in preparing these notes is to place on record the progress in our knowledge of Jade in its archeological relations. Some two or three years after my "Remarks" were printed in the Archoological Journal, vol. xlv., for 1888, Mr. F. W. Rudler, F.G.S., of the Jermyn Street Museum and Royal School of Mines, drew my attention to a paper he had contributed in 1879 to the Popular Science Review, "On Jade and its kindred stones" (see vol. iii., New Series). It is still worthy of perusal for general information on the subject, and particularly as to the localities where jade had theretofore 
been found; these words occur at page 345 of that volume :-

No jade has ever been recorded from Africa, and it is extremely doubtful whether it occurs in Europe. It is said to have been found in the form of boulders at Potsdam, near Berlin, and at Schwemsal, near Leipsig. It remains, however, uncertain whence the mineral was originally derived, and whether it had been transported by natural or human agency. In the great Exhibition of 1851, there was a large mass of pale green jade reputed to have come from Turkey; but nothing more was known of its origin, and its existence probably does not vitiate the general statement that no true jade or jadeite has yet been found in situ in Europe.

Mr. Rudler also wrote the article on jade in the thirteenth volume of the Ninth Edition of the Encyclopedia Britannica published in 1881, he there says :-

So far as it is at present known, no true jade has been detected in situ in Europe. A loose block has been found at Schwemsal, near Leipsig, and the mineral is said to occur at Potsdam. Corsica and Turkey have also been recorded as jade localities, but probably on insufficient grounds.

Much conjecture has been the outcome of the limited localization of jade in situ, which must give place to the record of new facts. Here, again, Mr. Rudler comes to our help. At the Meeting of the British Association, held at Leeds in October, 1890, lie read a paper on "The present aspect of the jade question;" the Association does not publish papers in extenso, but a summary of what he read appeared in print as follows :-

It has long been known that implements worked in jade have occasionally been found in ancient graves in France and Western Germany, and in certain neolithic stations on the Swiss lakes. Some of these implements are wrought in nephrite, or true jade, and others in jadeite. As neither of these minerals had been found in situ in Europe, while both were known to occur in Asia, it had been conjectured that the European jade implements must have had an Oriental source, and that either the implements themselves, or the raw materials of which they were made, had been brought to Europe in prehistoric times. But within the last few years Herr Traube, of Breslau, has discovered nephrite in place near Jordansmühle, and near Reichenstein, in Silesia. Pebbles of nephrite have also been recently recorded by Dr. Berwerth, from the valleys of the Mur and the Sann, two rivers in Styria. A pebble believed to be of jadeite was found by $M$. Damour at Ouchy, on the Lake of Geneva, and the same mineral has been recorded from Monte Viso, in Piedmont.

Jade implements are found along the coast of British Columbia and Alaska, and it has been suggested that these, or the raw jade, had been obtained from Siberia, where the occurrence of nephrite is well-known. Dr. G. M. Dawson has, however, recorded the discovery 
of small boulders of jade, partially worked, in the lower part of the Frazer River Valley: and Lieut. Stoney has obtained the mineral in situ at the Jade Mountains in Alaska, 150 miles from above the mouth of the River Kowak.

The present aspect of the jade question is, therefore, quite different from that which it presented when the late Professor H. Fischer and others strongly favoured the view that the jade implements of Europe and America had an exotic origin. In both these continents jade has now been found in situ, and it seems, therefore, probable that the material of the implements is indigenous, as maintained by Dr. A. B. Meyer for those of the Old World, and by Dr. Dawson, Professor F. W. Clarke, Mr. G. F. Kunz, and others, for those of the New World. If future discoveries should confirm the indigenous view, the famous jade question will be lifted out of the domain of anthropology.

Whatever proceeds from Mr. Rudler's pen on Geological or Mineralogical matters is authoritative, and becomes a scientific record of fact up to date. We are further indebted to him for another memoir which he read at a meeting of the Anthropological Society on 13th Jan., 1891, which will be published in their Journal; meanwhile, however, the following note thereof has appeared in the Athenceum of 24th January, 1891-

Anthropological Institute.-Jan, 13th, E. W. Brabrook, V.P., in the chair. Mr. F. W. Rudler read a paper on "The Source of the jade used for ancient implements in Europe and America." Its object was to call the attention of anthropologists to certain mineralogical discoveries which have been made within the last few jears, and which tend to overthrow the well-known theory which suggested early intercourse with the East as the source of the jade objects found in the lake-dwellings of Switzerland, the pre-historic burial places of France and Germany, and the ancient Indian graves on the northwestern coast of America. Herr Traube, of Breslau, first recorded the occurrence of jade in situ at Jordansmühle, in Silesia, and afterwards discovered it at the arsenical-pyrites workings at Reichenstein. Rough pebbles have also been found in the valleys of the Sann and the Mur in Styria. Dr. G. M. Dawson has described the occurrence of boulders of jade partly sawn through at Lytton and Yale, on the Frazer River, and Lieut. Stoney has actually found the mineral in situ at the Jade Mountains, north of the Kowak River, in Alaska. These discoveries prove that, contrary to general belief, jade does occur in the rocks of Europe and of North America, thus supporting the views so long held by Dr. A. B. Meyer, of the Royal Zoological Museum in Dresden, and accepted in America not only by Dr. Dawson, but by Prof. F. W. Clarke and Mr. Merrill, Mr. Kunz, and others. In England most anthropologists have hitherto inclined to the exotic rather than to the indigenous origin of the prehistoric jades.

This touches particularly the archæological consideration of jade, as well as such of my "Remarks" as appear at voL, XLVIII 
pages, 192, 194, 195 and 204 of the Archcoological Journcul, vol. xlv. It is of much interest to those who are watching all jade questions, and suggests the probability that as we become better acquainted with the earth's surface more jade-bearing rocks will be brought to notice than are yet known of; our adopted beliefs about jade will be modified and inferences corrected. The question to be solved affects the finding of shaped implements belonging to a prehistoric period, in the great ruin-mound at Hissarlik, in the caves at Mentone, in the gravel of the Rhone Valley near Geneva, in Brittany, and at the submerged remains of the Swiss lake-dwellings. From whence did they come? No one will doubt that the Chinese people fetched their jade from their own Asiatic quarries; but no one will venture to say that the New Zealander exported his green jade to the shores of Brittany, or to affirm what race of men brought jade weapons to that region and buried them under the dolmens at Carnac, although those weapons, it is said, resemble in colour the New Zealand jade. The question is not confined to Europe, it relates also to the American Continent in all its bearings. Let the fact be always remembered, that there is a material difference between true jade and jadeite. The numerous known jade-like minerals may lead to erroneous conclusions, but we may look to Mr. Rudler for intelligent guidance to avoid them. A comparison of the prehistoric implements with rock specimens alluded to in his several papers would be a good starting point. As jade is a mineral of rare occurrence, it may be possible to identify some of those implements with jade rock in situ at any given locality, and so we may hope to arrive at the origin of some prehistoric implements of that material. Jadeite resembles jade only in appearance, analysis shows it to be a different mineral.

To Mr. Rudler my thanks are due for permission to use his contributions to the literature of jade.

In my "Remarks" I alluded to the finding of jade boulders in British Columbia; also to the supposed existence of jade-rock in Brittany. On this last point I suggested strong doubts, which derive some support from the "Catalogue raisonne des minéraux du Morbihan, par le Cte. de Limur" (member of many Societiss, 
inter alia, the Geological Society of France, and the Mineralogical Society of France), published at Vannes, 1883. Under the group of jade-like minerals named "Oligoclase," Plagioclase is thus described:-

Compacte, blanc, avec pyroxene en grains ou en lamelles, vertegrisatre et idocrase brune amorphe (Jade-Breton), rochers de Roguedas. . . . . Un bijoutier de notre ville fabrique, avec cette roche de Plagioclase Pyroxenifere, sous le nom de Jade-Breton, des petits objets de luxe qu'il vend fort cher, vu sa dureté et la difficulté de le polir."

(The writer goes on to mention the stone or jade weapons found, but he does not state that they are made of the local rock in Brittany.)

It will be interesting to know whether the discovery reported in Germany, is of jade-rock in situ at the surface, or arrived at through the work of excavation; if the latter we must be cautious in supposing that primitive or nonhistoric man so procured his supply, but even supposing that he did, it is remarkable that so limited a number of jade implements have come to our knowledge, as compared with implements made of other stone material, which are almost innumerable. As appropriate to this point of inquiry- $I$ will add the substance of a communication which reached me quite recently from Mr. Chas. Seidler, who has devoted much attention to our subject; with his permission I give his own words :-

The discovery of a few boulders here and there, or even the occurrence of jade in situ in Silesia does not solve the question of where the numerous worked implements found in various countries come from. The rough material was worked up somewhere, and where it was worked chips and refuse pieces ought to be found, and where has such a "workshop" come to light? No mention of such a place of manufacture at Jordansmuihle, or indeed anywhere else, is made, and yet what a number of places are known strewed with refuse flakes of flint? I have a collection of minute implements made of chalcedony, agate, moss-agate, carnelian, rock crystal, and jasper found in caves and rock shelters of the Findhya Hills, Central Provinces of India. But with these finished implements of such unusual materials were found flalses and cores, showing conclusively that the manufacture had taken place on the spot.

Later on some facts are quoted which in some degree meet this suggestion. A near approach to the ancient manufacture of jade implements may be seen in the recently arranged Ethnological Gallery in the British Museum : in a case of American objects, there is a piece of dull green jade from Lillooet on the Fraser River in 
British Columbia, about fifteen inches long by about three or four wide, partly sawn through in the straight line of its length, as if for the formation of a weapon; also another smaller piece, mottled green in colour, showing a like mode of treatment; both are out of the "Christy Collection." These, and the examples from the Fraser River of other pieces of jade partly sawn through, mentioned by Mr. Rudler, raise a strong presumption that the material which they represent had its origin in the North American Continent, especially as jade is reported to occur in situ in the territory of Alaska. The distance, however, of Lillooet from the southern boundary of Alaska may be judged, from the map, as about 600 miles.

All who are interested in the subject are referred to the South Kensington Museum and the Indian Museum for some most remarkable works of art in carved jade; and to the British Museum for the very extensive collection of stone implements from European and other localities, it is in the hall at the top of the main staircase and in the room adjoining on the left hand. A large collection is also in an "American room" now in course of arrangement, comprising a few jade implements; also in the Ethnological Gallery a very important collection of jade weapons and objects from New Zealand is exhibited, while in the drawers beneath is a great collection of similar treasures, the manufacture of which by the natives of that island country has ceased; a piece of green jade about fourteen inches long, split to form a weapon, and worked on one side with a groove as if it had served for rubbing other pieces into a desired form, is exhibited with the finished objects. The book by Mr. John Evans, F.S.A., on the Stone Implements of Great Britain; that of Dr. Ferdinand Keller (translated) on the Lake Dwellings of Switzerland and other parts of Europe, edition 1878; and that of Dr. R. Munro on the Lake Dwellings of Europe, edition 1890; are conspicuous among a multitude of others as authorities on the whole subject.

Keller says on page 195-

How are we to explain the presence in our lakes, of stones which have come from such a distance... on the supposition that the migrations of man have caused it. It seems to me that the issue of 
commercial relations between Switzerland and the East by people who did not even know the use of metals, still less of the art of writing, ought to be laid aside as a simple absurdity.

And at page 215 he says-

That out of a large number of stone implements in one particular locality, only two small celts of jadeite have been found, also one other of a beautiful dark green nephrite [i.e., jade] with a perfectly cutting edge.

(This conclusion is affected by the facts quoted later on.)

A French pamphlet gives some interesting though not recent information, the title is "Le Jade, Etude historique, archéologique et litteraire sur la pierre appelee $\mathrm{Yu}$ par les chinois." Par S. Blondel. Paris 1875. It describes the analysis of jade-stone, the localities in China where it is found, the different colours and quality, the estimation in which it has been held by the Chinese, and the poetic, flowery, and figurative allusions to jade as expressive of all that is good and beautiful; the early dates recorded in Chinese literature when jade was an article of tribute to the Emperor from the province of Khotan, are about the time 965 A.D. and 1167-70 A.D. As to the medicinal qualities of the stone (at one time named nephrite, then jade) it was regarded as a remedy for "nephritic colic," and affections of the kidneys, it was not taken inwardly but was worn by the sufferer as an amulet. The brochure touches but lightly on the archæological questions.

I hasten now to the highly important work of Dr. Munro, Secretary of the Society of Antiquaries of Scotland, and with his kind permission I have made some extensive quotations bearing on the archæology of jade. The title is, "The Lake Dwellings of Europe; being the Rhind Lectures in Archæology for 1888. By Robert Munro, M.A., M.D." London, 1890. We learn from the preface that it was prepared by the author after four years of travel throughout Central Europe, undertaken on purpose to acquire accurate information on all matters connected with the subject. Great attention is paid to the jade question; his narrative contains such a mass of information not hitherto brought together, or but little known, that long extracts are needful in order to bring our archæological knowledge of jade down to the present time most of the discoveries recorded having been made some ten years ago. It is surprising to find how numerous 
are the specimens of anciently worked implements of jadestone which in recent years have been found in Europe, and are now preserved in museums and private collections. The work is illustrated by a profusion of engravings from the author's original drawings, and concludes with a Bibliography of at least 469 separate works on the Lake dwellings of Europe. The author frequently uses the word "nephrite," the early expression among mineralogists to signify the stone, which in a less scientific way has been called jade, and which, as I have already pointed out, means a mineral which is not jadeite or chloromelanite, though all the three resemble each other. He uses the word jade in a somewhat generic sense to cover the various forms of the mineral nephrite, jadeite, \&c. Hence in ordinary English a jade implement might be either the one or the other. At page 498 we learn that-

"One of the stations in Moosseedorfsee the remains of the lakedwellings became completely exposed in consequence of drainage operations, and was carefully examined by experienced archrologists, it yielded a large assortment of osseous remains . . . and cultivated plants . . . Among an assortment of its industrial remains now in the Berne museum, are about a dozen celts of nephrite, one of jadeite, and many articles of pottery \&c."

Heavy objects dropped into the water at these ancient dwellings are now found in the peat and soft mud and sand beneath here they once stood, the author says at page 500 that-

Arrow-points of fint and sometimes of other minerals, rock-crystal and jade, and of bone, are amongst the most common relics.

At page $505,-$

"In the museum of Zurich there is a large water-rolled stone of serpentine ${ }^{1}$ measuring 14 by 9 by 8 inches which was dredged up at Wollishofen, showing a cut 11 inches long and $\frac{5}{8}$ inch deep. One side of the cut was broken off, but the fragment was found and it fits the place, proving the breadth of the cut to be $\frac{3}{8}$ of an inch. No problem has for many years puzzled archæologists more than the effort to account for the finding, from time to time in various parts of Europe, of those remarkably elegant implements made from the mineral substance commonly known as jade. Hitherto they have been generally found isolated in the soil or in graves of the Stone Age, such as the dolmens of Brittany. The favourite theory, seeing that no local habitat could be assigned to this mineral, was that these implements were imported by the original neolithic people, who were supposed to have migrated westwards from the plains of Northern India. The

1 This mineral often resembles jade, but it is very soft in comparison. 
discovery of a large number of celts and small chisels in the lake, dwellings, together with a few other objects made of nephrite, jadeiteand chloromelanite, has reopened the problem as to their origin, with the result, however, of making the controversial flame burn brisker than ever. Independent of the lake-dwelling finds, the number of jade objects now known in Europe may be roughly stated at 200, ubout the half of which come from some 44 departments of France. Of the remaining 100 about 80 are from Western Germany, the rest being assigned to various localities in Italy, Austria, and Greece. According to the opinions of competent mineralogists the vast majority of those from Western Europe are made of jadeite and chloromelanite, the number made of the former being slightly in excess of the latter. In the French group there is only one of nephrite, from the vicinity of Rheims, and in the German group three or four, found in Baden and Bavaria. Mr. A. B. Meyer states that, with the exception of one from Posen, all the German examples were found to the west of the Elbe. In appearance nephrite, jadeite, and chloromelanite closely resemble each other, and, owing to considerable variations in the colour to which they are all more or less liable, it is difficult to distinguish them by the unaided eye. Generally speaking nephrite has a somewhat soapy feel, with a lighter and more transparent tint of green than jadeite, while chloromelanite is darker and less transparent than either. From the large number of implements, especially hatchets, small chisels, and sometimes lnives - rarely arrow-points and ornamentsfound in almost all the lake-dwelling stations of the Stone Age, it would appear that they were greatly admired and much sought after by the inhabitants of these settlements. Dr. Gross thinks they were in greatest abundance in these stations which flourished in the period immediately preceding that of the introduction of metals, and that after this event they disappear altogether.

At page 507 Dr. Munro sums up the number of jade implements found at the Swiss lake-dwelling stations, having, as we have already seen, enumerated those found at other places in Europe ; he says-

From Lake Constance the number of jade implements now considerably exceeds 1000, as may be verified by an inspection of the museums in the neighbourhood, one station alone, Naurach, on Lake Constance has supplied 349 tolerably well, and 141 badly, made implements, and no less than 154 chips and sawn portions varying from the size of a finger-nail to a few inches. Similar chips have also been occasionally met with in other stations. This at once settles one important point, viz. that the lake dwellers were in actual possession of the raw material, which they worked on the spot. Although most of the settlements in Lake Constance have yielded more or less specimens, there is none that even approaches Maurach in point of numbers, the next highest being Unter-Uhldingen, Immenstadt, and Sipplingen, from each of which two or three score have been collected. In moving eastwards towards the I/anubian valley they became much rarer. According to Fischer 97 per cent. of the implements from Lake Constance are of nephrite, while the other 3 per cent. are nearly equally divided between jadeite and chloromelanite. In the Zurich Museum he found 
28 implements of nephrite, one of jadeite, and 6 of chloromelanite, out of the former, 22 are from Meilen, and 4 from Robenhausen. Out of 295 in the museums of Berne (which came from the lakes of Neuchatel, Bienne, Morat, Inkwyl, and Moosseedorfsee), 118 are of nephrite 124 of jadeite, and 53 of chloromelanite. From these approximate calculations we see that while nephrite was greatly in excess of jadeite in the settlements of Lake Constanceand its neighbourhood, this inequality becomes gradually removed as we move westwards, till we come to France, where their relative frequency becomes actually reversed. Chloromelanite, on the other hand, though as a whole much rarer than either nephrite or jadeite, seems to have been more evenly distributed. Roundly speaking we have in all Europe between 300 and 400 worked objects of jadeite, and about 200 of chloromelanite, while those of nephrite amount to twice these numbers combined.

Thus the jade implements, known to have been found in Switzerland and other parts of Europe, reach a total of 1200. The next remark by Dr. Munro is important; at page 508 he says-

These facts are very suggestive, and undoubtedly give some support to the theory that these minerals were found by the lake-dwellers somewhere in their own neighbourhood. But notwithstanding the most careful searching on the part of geologists and mineralogists not a particle of any of them has yet been found in situ in any part of Switzerland. As an inducement to country people to be on the look-out a reward of 200 franos was offered a few years ago to anyone who could produce a bit of nephrite, found in situ of the size of a man's fist, but as far as I know, the reward still lies unclaimed. Three isolated portions have been found in Germany, one in the alluvial sands of Potsdam, another in the vicinity of Meersburg, and a third in the vicinity of Leipzig. Also in somewhat similar circumstances two portions have been recorded from Styria. It is said to have been found in situ in small quantities in the rocks of Silesia . . at Jordansmuhi. And in the Canton Freiburg as stated in a work published in 1834. Also a few chips were found in the prehistoric caves at Mentone associated with worked flints, (see Archaological Journal, xxxvi). To these remarks on the jade question $I$ have only to add that Dr. Arzruni maintains that the nephrite and jadeite of the lake-dwellings can be microscopically shown to differ from the Asiatic mineral."

The finding of thirteen small implements of jade at the prehistoric city of Troy, by Dr. Schliemann, is alluded to in the Archaeological Journal, xlv, p. 196. One other remark by Dr. Munro is deserving of consideration; at page 533 he says-

"The extraordinary number of implements and chips of nephrite found at Maurach, and the equal predominence of flint refuse and implements in all stages of manufacture at some of the other stations suggest the idea that the various industries prosecuted by the inhabitants of the lake-villages had already developed to such an extent as to become localized in certain centres," . . "That the lake-dwellers 
kept up commercial relations with foreign countries is proved by their possessing materials, not only peculiar to distant or limited areas, such as amber, jade, flint, etc. but also certain objects having such peculiarities in form or style of ornamentation as have enabled experienced archeologists to trace them to their original areas of evolution."

The foregoing extracts add very much to our knowledge by telling what is new to students of the subject; they should have the careful consideration of all who are pursuing the enquiry with an unbiassed mind. The finding of so many implements in Europe, whether they be of all true jade or other kindred mineral, while we know of only two or three remote places where jade is known to exist in situ, rather encourages the belief that non-historic man procured the material from drifted rubble, a mixture of all sorts of rock tossed about by water torrents, and transported about in long past ages by floating ice and glaciers from incalculable distances and unknown localities. The proofs of such natural forces are patent to all geological observers, and can be no more called in question than those of a like character constantly taking place before the eyes of the present inhabitants of the earth's surface. Boulders and stones of jade can thus have been scattered over Europe. as easily as stones of granite or other kinds of rock whose home can be identified. It seems likely that non-historic man picked up and appro. priated these stones, and did not work the rock in situ, or in quarries, which we now know requires the use of iron tools and manufactured explosives. But this view is not conclusive while the question is unanswered, why is this drifted material so exhausted that in the present day no jade is to be found in any of the existing deposits yielding almust every rock substance but jade. As for the jade in situ at Jordansmiihle we cannot yet regard it as evidence that it was known, much less that it was worked in ancient times, or rendered available by the makers of the discovered implements. More facts are required before it is safe to dispose of the question which is so perplexing to archæologists. 